THE WABASH CENTER

JOURNAL on TEACHING

\title{
After the Protests Are Heard: Enacting Civic Engagement and Social Transformation
}

\author{
Sharon D. Welch \\ New York, NY: New York University Press, 2019 (272 pages, ISBN 978-1479857906, \\ \$28.00)
}

\section{Reviewed By \\ Xochitl Alvizo \\ California State University, Northridge}

Starting with the premise that the Trump administration signaled not the death throes of white supremacy but the pangs of its rebirth, Sharon D. Welch calls on liberals and progressives to take responsibility to mitigate evil. In her book After the Protests Are Heard: Enacting Civic Engagement and Social Transformation, Welch urges her reader to help contain seven windigos, among them rapacious globalization, exploitative and extractive capitalism, greed, and domination, and to do the work of building and enacting progressive politics. She writes this book for a broad progressive audience and exhorts those who have some level of social and economic power to do more. She boldly calls out white progressives in particular for failing to "work with our fellow African Americans, Latinx, Native American, and Asian American citizens to do what was needed" to stop authoritarianism and explicit racism's "resurgence now and prevent its rise in the future" (3).

Welch invites progressive activists and institutional insiders to move from "prophetic witness and critique" to building the goal and vision that inspires their activism in the first place. Challenging the reader to give up on the notion of assured linear progress, she provides theories, tools, and practical examples to intentionally enact "our expansive best and contain our defensive and insular worst" (194). Its central thrust is toward an ethic of reciprocity and belonging that accounts for the human capacity for both evil and justice, instead of an ethics of "the savior who solves problems for others" (40-41).

To resource her readers for informed, strategic, collaborative-minded, and responsible action, Welch covers multiple theories of social change-what has worked, what has not, and what can be learned. She explores these theories based on research studies of various movements in order to identify their strengths and weaknesses. Key among the weaknesses she identifies is the lack of leadership which is needed to follow prophetic critique with "catalytic engagement" for social transformation. Her goal is to equip progressives for responding to the "theological and ethical imperative of prophetic critique" with "power, creativity, and ongoing self-critical accountability” (51).

After the Protests Are Heard provides practical examples of "direct institutional change" through stories of actual small businesses, socially responsible investing, and community economics (78-98); all are meant to highlight "environmentally sound and socially just economic development" (77). Welch grounds the various tools and technologies for living out "practices of plentitude" in a vision of "a beloved community of generative interdependence" (128-133). In her drive to have liberals and progressives live out their values in businesses, schools, parenting, and civic life (20), she challenges her readers to live into the yes of beloved community actively, creatively, and responsibly.

Identifying herself as one who has been an activist protesting from the outside demanding change of those on the "inside," and now one who finds herself on the inside of institutional power, Welch contributes a practical resource to the scholarship of religion and social transformation, religion and social justice, civic and community engagement, and social ethics. Her book is a timely resource for both the practical theological and religious studies classroom offering concrete models and theoretical accounts aimed at expanding the student and future leaders' imagination for civic engagement and collective action. She concludes the book with a discussion guidebook for use by groups or for self-reflection (196). This book can be used in the undergraduate and graduate classrooms of religious studies and practical theology with both the novice of civic engagement and the seasoned leader ready for a new resource. 